\title{
The Practice Teaching Platform and System for Innovating Talents and Performing Research
}

\author{
Boyu Wang ${ }^{1} \&$ Ziqiang $\mathrm{Hao}^{2}$ \\ ${ }^{1}$ Office of Academic Affairs, Changchun University of Science and Technology, Changchun, China \\ ${ }^{2}$ Electronic Information Engineering College, Changchun University of Science and Technology, Changchun, \\ China \\ Correspondence: Boyu Wang, No. 7089 office, Changchun University of Science and Technology, Weixing road, \\ Changchun 130022, China. Tel: 1-362-431-2192.E-mail: wbyanzhan@163.com
}

Received: December 10, 2013 Accepted: January 14, 2014 Online Published: January 24, 2014

doi:10.5539/hes.v4n1p75 URL: http://dx.doi.org/10.5539/hes.v4n1p75

\begin{abstract}
The practice education is an important part of higher educational system and an important approach to cultivating applied innovative talents. This paper studies practice of teaching platform and practical teaching system for the research and practice based on the objective basis of applied innovative talents and the basic characteristics of the practice educational system.
\end{abstract}

Keywords: applied, innovative talents, the practice teaching platform, practice teaching system

\section{The Research Purpose and Meaning}

In 1999, China began to undertake large-scale enrollment expansion of colleges and universities, which transforms higher education from "elite education" to "popularization" and results in the conflicts between social needs and poor quality of the talents who cannot adapt to social development requirements. Under this background, the goal of talents training is also adjusted for applied talents. But, as the university develops into comprehensive, open, and high level teaching and research university, how to adjust the training mode, curriculum system, especially practice course system, how to strengthen the link between practice and teaching, how to produce the applied talents who has strong practical ability and innovation ability to meet the needs of society, how to melt practice education into the whole process of talent training to cultivate college students' innovation ability, how to build practice teaching platform and practical teaching system to improve the quality of talent training, become an urgent problem in the undergraduate education.

\section{The Research and Practice of Practice Teaching Platform and Practical Teaching System}

\subsection{Update the Teaching Ideas of Practice Education}

For mission and task of local colleges to cultivate applied talents, we should constantly update teaching idea, pay equal attention to practice teaching and theories teaching, put forward the concept of "taking the student as the main body and maintaining the whole process of practice education" in applied innovative talents training, that is to implementing the cultivation of the students' innovative spirit and practice ability training throughout the whole process of education, including training objectives, major setting, curriculum structure, training methods, teaching, organization and evaluation mechanism, etc. We should adhere to the principle of "practice ability training for four continuous years", strengthening practice link, and highlighting practical education as the important position in the talent cultivation. We also need to implement the "four combinations", namely the combination of theory and practice, the combination of knowledge, ability cultivation and quality education, the combination of teaching and research, and the combination of teaching with engineering practice.

\subsection{Build and Improve the Four Levels of Open and Efficient Three-Dimensional Practice Teaching Platform}

Under the background of "big project" and through the construction of practice teaching demonstration center, the university further standardizes the management, increase investment in experiment teaching, strengthening the construction of teaching laboratory, open national and provincial key laboratories and engineering center, consolidate and strengthen the cooperation between colleges and factories, build the construction of off-campus practice teaching base, integrate high quality teaching resources, set up the four levels of open and efficient 
three-dimensional practice teaching platform with the combination of teaching and research and the combination of the on campus and off campus resources, namely the basic experiment training platform, subjects practice teaching platform and engineering practice education platform, and science and technology innovation practice platform.

1) Build a high level foundation experiment training platform with the construction of experimental teaching demonstration center.

In accordance with the principle of "overall planning, key construction, resource sharing", the university should vigorously promote the reform and construction of teaching laboratory. By integration and transformation of the original laboratory, we set up an open public basic experiment teaching and professional basic experiment teaching platform to provide a similar experiment in multiple close subjects teaching. In accordance with the students of the different majors and different grades, we implement experimental teaching of different phases and levels. The university also raises funds in many ways to improve the school condition of experiment practice teaching, and set up complete experiment teaching platform from low level to high level and from basic experiments to professional experiments, covering the seven disciplines, 52 undergraduate majors. Currently we have nine experimental teaching demonstration centers, three national experimental teaching demonstration centers, and seven provincial experimental teaching demonstration center, which formed high level of experimental teaching platform from three aspects of schools, colleges and departments.

2) Construct the discipline practice teaching platform based on the advanced discipline and the scientific research resources.

With the situation and characteristics of the national and provincial key laboratories, engineering center and the construction of key discipline laboratory, we maximally open them to undergraduates. We transform the high quality disciplines, scientific research resources into teaching resources more efficiently, and design the cutting-edge and creative experimental topic. At present, the school has developed more than 150 experiment topics, so that the students can contact the dynamics of the cutting edge discipline knowledge, which can stimulate their science consciousness and innovation.

3) Build engineering practice education platform by making university-enterprise cooperation as the breakthrough point.

Schools and businesses cooperate in multiple levels and multiple dimensions, on the one hand, the school selected teachers to enter the enterprise to directly contact with the production line of new technology, new technology, and integrate them into the teaching content. Schools employ enterprise engineers and technical personnel, on the other hand, to offer practice guidance to students, which forms the training mode with interaction between colleges and enterprise. Students participate in project development and the management in the process of training, so as to exercise the students' professional awareness, professional quality and ability.

4) Aiming at college students' innovative ability, construct open platform of science and technology innovation practices.

Schools actively explore the practice teaching mode of using scientific research and training projects, and the innovation practice activity as the carrier to build the open innovation platform of science and technology to develop the students' practical ability, research ability and innovation ability training for integration. At present, the school has four college students' science and technology innovation practice base. Every year nearly thousands of students enter into the innovation practice base to take part in practice activities, and the school each year makes 2 million yuan of special funds to support base running. Along with the college students' innovative projects, each year about $70 \%$ of college students participate in the innovative practice ability training.

\subsection{Build and Improve the "Four Levels, the Two Interaction, and a Line" Practice Teaching System}

Practice teaching is very important in the whole process of talent training, and plays an important role in the coordinated development of students' knowledge, ability and quality. Based on the talents training goal and professional talents, and on the basis of demand analysis, school takes the top design method, carry out the practice teaching reform and innovation, and reconstruct practice teaching curriculum system. The school also develops a detailed outline for knowledge ability quality, to realize integration and optimization of the content of the practice course outline.

In recent years, we have carried on the positive exploration and practice of teaching reform practice in the teaching and learning. The key is to carry on the integration of design and reform of practice curriculum system, teaching contents, teaching methods and means, and teaching management. To set cultivation of students' 
practice ability and innovation ability as the core and training of high quality applied innovative talents as the goal, we establish and perfect the practice teaching system "four levels, the two interactions, a line":

1) Four levels: the comprehensive design experiment practice, basic experiment training, education of science and technology innovation and engineering practice training four layers.

Basic experiment training is for the entire school basic experiment practice link, and the emphasis is on the simulation, advanced and integrity, simulating occupational environment as far as possible. Especially professional training experiment can directly contact with the production line, which has mature and widely used technology and simulation environment, and makes the teaching environment and conditions close to the production line.

Comprehensive design experiment practice mainly refers to optimization combination experiment course, which makes the students master the basic skills in the comprehensive designing experiments, and use knowledge to solve practical problems.

Engineering practice education build training platform for the students specializing in the production and engineering application oriented with the most basic engineering and operation skills training.

Science and technology innovation training relies on the advantage of subjects, integrates into the scientific research and engineering practice, restructures and optimizes the design of the large comprehensive experiment and comprehensive subject. The purpose is to undertake training of the students' scientific research ability, including curriculum design, students' participation in the teachers' scientific research project, and graduation design (paper).

2) Two interaction: interaction between classroom activities and extracurricular activities and interaction between campus off-campus activities.

In-class activities include practical teaching such as course design, course thesis, graduation design in addition to the experiment and training. And the interaction with student associations, clubs, and all kinds of training, textual research employs, independent practice, course contests and extracurricular links such as science and technology activities and off-campus practice base is constructed to build benign interaction of classroom teaching and extracurricular practice in practice teaching system.

Schools continue to expand the practice teaching base construction for training students' practical ability on and off campus environment. Two practice base in the school focuses on training students' basic skills, professional skills and innovation spirit, etc. In the outside the base (enterprise) students cultivate the professional practice ability through contact with society to carry out the production practice, field work, social services, the co-operative education, which realizes the interaction between the on campus and off-campus.

3) A line refers to the practice from the basic theory, the design scheme to the application of the theory.

School always thought to provide quality qualified products "talent" to society as the goal, constantly perfect the practice teaching system which has its own characteristics. Considering the practice as a whole, the goal of talent cultivation is decomposed into each target, according to the inner link between knowledge and ability. Through each cell, each teaching link, we can achieve the overall grasp of knowledge and ability structure, we can finish the process of decomposition and implementation of the experiment, practice, course design and graduation design into the practice teaching link, build knowledge ability matrix, and achieve the final solidification to practice teaching plan and teaching outline in practice.

\subsection{Reform of Practice Teaching Content and Teaching Mode}

Practice teaching course content are designed according to the different "phases, hierarchies, and modules", to adapt to the students of different grade, different levels and different professional and the different needs of personnel training requirements.

1) Sweep aside the course barriers and integrate the experiment teaching content.

We should emphasize the systematic, comprehensive and designing of the course content and openness, increase practice teaching hours, increasing the proportion of practice teaching, make the science and engineering practice teaching credits reached $25 \%$ of the total credits, the practice teaching of liberal arts credit amounted to $15 \%$ of total credit, optimize the experimental project configuration ratio, reduce the verification experiment, increase the opening of a comprehensive, design, innovative experimental project, and make the proportion of more than $80 \%$.

We also need to break through barriers and disciplinary boundaries, integrate the experiment course and project, 
reduce the verification experiment, increase comprehensive and designing experiment, open innovative experiment to help the student to grasp the experiment based method of system and basic skills and use the learned knowledge to solve practical engineering problems in the designing and comprehensive experiments, and develop a scientific way of thinking and normative research methods. Now in our school, we have opened more than 4000 experimental projects, the comprehensive, design, and innovative experimental projects account for more than two-thirds.

2) Use "open" and "project driving" teaching method.

In recent years, the curriculum broke the traditional way of teaching in the classroom which makes teaching as the main body, separately from the theory and practice. Therefore we have made research and innovation in the teaching mode and method of the comprehensive training students' ability and teaching, evaluation of the original curriculum structure, teaching material system, teaching mode, teaching organization form of structural reforms, which has received good effect of practice teaching.

First is the opening of teaching content, the teacher only teaches experiment points and matters needing attention, and students complete tasks to get the corresponding innovation credits through discussion. This makes the students learning transform from passive learning to active learning. With the open laboratory, students can use instruments and equipment in the laboratory throughout the day, according to their own schedule time to the laboratory to carry out the experiment within the prescribed time.

For example, the project driving teaching method: this method is not restricted by the books and the classroom, the students can thus be divided into several project teams in accordance with the requirements of the project, through team collaboration, independent work plan to finish the project task under the guidance of teachers, and finally accept evaluation. The professional practice teaching is basically use the driving teaching method such as numerical control technology, automation, engineering cost of the production process, the computer network technology, computer application, financial accounting.

3) Establish a "diversity" teaching method.

The teaching method gradually develops into "cultivating ability centered" teaching, the implementation of autonomous learning of taking the student as the main body and teacher as the leading factor, change teachers from "making experiment" to "guiding" experiment. By adopting the method of multimedia, the teachers can take the teaching resources on the Internet for students learning experiment content. For more abstract experiment content at the same time, a large number of software technologies such as computer simulation are adopted to improve the experiment teaching.

4) Put latest scientific research results into a comprehensive design experiment.

The teachers' latest scientific research project will be integrated into a comprehensive, innovative experiment design to enrich the practice teaching content, improve the practice teaching system, and effectively enhance the practical teaching effectiveness. such as project " teaching content and practice of machine design foundation experiment " developed by teachers, adding the "fischer creative design experiment", implementing the change from "participation" to "development"; "Photoelectric reform and practice of comprehensive experimental system" project, putting universality and further development as a whole. Students can design and develop board according to the needs of curriculum design, graduation design with platform interface.

Through the reform of practice teaching content, methods, we obviously improve the students' learning initiative and participation to guarantee the students' learning effect.

\subsection{To Strengthen the Construction of Teachers Team}

For excessive proportion of middle-aged and young teachers in teaching team, and poor engineering practice experience, the school carries on the teaching staff's planning and construction with an open mind and vision. Setting up a team of teaching faculty who have a modern education idea and innovation spirit, teaching ability, are familiar with the production field, and master high technology and high quality of teaching is a key to the process of practice teaching.

1) Organization of teacher's entering into enterprise to acquire learning experience.

Schools require every teacher in the first five years of employment to take part in at least 1 to 2 times enterprise training education experience, in-depth business practices, and engage in the production practice, technical development, and enterprise management to update the knowledge structure, and strengthen the practice ability. The school also encourages teachers and enterprise to carry out the horizontal scientific research, participate in the enterprise technology research project to make the teacher get practical engineering training, put their own 
practical experience into the teaching content, and blend the latest engineering knowledge in theory and practice teaching.

2) To form a team for high quality of practice course.

School sets the building of a team of practice teachers with high quality as the goal. The earnest analyze the present situation of practice teachers is drawn up according to the title, professional degree, age structure and all kinds of practice teachers demand plan to introduce the practice teachers in the school talent introduction plan, and the formation of a team of practice teachers of high quality. Today, electrical electronics, electrical engineering, and mechanical engineering experimental teaching center has built a reasonable structure with dynamic and steady development of the practice teachers' team, which has made many beneficial attempt for the national experimental teaching demonstration center construction

3) Complement and perfect the practice teaching structure.

In talent introduction, the school attaches importance to introducing some employees from well-known enterprises and research institutes at home and abroad with strong engineering background, and the practice innovation ability to be practice teachers. In the recent three years, the school has the introduction of more than 90 people from guangdong dongling KaiQin group co., LTD., Shanghai institute of optical precision machinery, Howe companies in the United States. The new comers bring the first line of production, management, research of new technology, new technology and new demand of society to the employee's ability quality, which greatly optimizes the structure of teachers.

\subsection{Build Practice Education Guarantees Mechanism and Atmosphere}

The improvement of talents cultivation quality can't ignore the fact that the quality of teaching monitoring is an important means and ways. In the teaching process, we should put the quality consciousness, quality monitoring and evaluation through a variety of system and ways throughout the open practice teaching process.

1) Establish the practice teaching management guarantees mechanism.

Successively formulating and revising a series of school management system for experimental teaching, practice teaching, graduation design, course contests in major different levels such as school, college, and department, to form the corresponding practice teaching rules and regulations to safeguard work and the smooth implementation of education practice.

2) Improve the practice teaching quality monitoring system.

University will put the practice teaching quality monitoring throughout the course of practice teaching, and build a three level practice teaching quality monitoring system of a school, college, and the students. At the university level, we should carry out the quality evaluation and quality analysis by using the management information system through in-depth laboratory research, and organize a practice teaching summing-up meeting to make the comprehensive summary on the practice teaching; at the college level, by conducting the mid-term examination, the comprehensive summary on the practice teaching is implemented. In the student's level, with regular students' meeting and students' report on the practice off campus, we can swift the quality monitoring from the single angle to multiple points of view.

3) Establish and improve evaluation system of college students' practical innovation ability.

With reform of the traditional "focus on theoretical knowledge test, and ignorance of practice ability evaluation", the school puts the analytical ability and innovative ability as the main content of the assessment. On the one hand, single exam of the theory is changed into the exams of theory and skills, which will attract the students' attention to the usual practice. on the other hand, the school constantly improve college students' practical innovation ability evaluation system, whose evaluation contents include the practice teaching link, the students' practical innovation ability of various competition awards, students study result, practical innovation, students' participation in extracurricular activities of science and technology, and the objective result and process occupy $70 \%$; the teacher's evaluation, evaluation of internship, and students' self-evaluation and mutual evaluation account for $30 \%$.

\section{The Effect of Practice Teaching Platform and Practical Teaching System}

\subsection{The School Strength Increasing, the Construction of Practice Teaching and Reform Has Made Significant Effect}

The school has built 36 completed laboratories, 12 on campus practice bases, and 144 off-campus practice bases covering all majors. Through the laboratory, the construction of practice and training base, we greatly improve 
the students' engineering practice ability, shorten the distance of the student and the enterprise, as well as laid a solid foundation for the students' employment and better adaptation to the requirements of enterprises, which provides a strong support for realizing our school's talent cultivating target.

School now has four national experimental teaching demonstration centers ahead of other local colleges, 3 national engineering practice education centers, six experimental teaching demonstration centers of jilin province (including "computer experiment teaching center", which declares a national experimental teaching demonstration center and passes the examination of jilin province which has been submitted to the ministry of education for the record) and two college students' innovative practice base of jilin province. The school has been approved for implementation of the national college students' innovative experiment program by the ministry of education (only 120 colleges and universities across the country and only 2 provincial colleges and universities) and the national college students' innovative entrepreneurial training plan implementation school.

\subsection{The School Personnel Training Quality Are Improved Greatly}

Schools put the implementation of the open practice teaching as the key points in education teaching reform. Students get good grades in the contests such as "challenge cup", "mathematical modeling", "electronic design competition", and "programming contest" for many times throughout the country and the province by taking advantage of the open laboratory to carry out a series of scientific and technological innovation activities. In recent five years, students did well in all kinds of college students' science and technology competition, won a silver medal and 2 bronze in Asia and won the national prize 604 (15 national star prizes, 77 national first prizes, 202 national second prizes, and 310 national third prizes), and 667 provincial awards. There are totally 424 projects of college students' innovative entrepreneurial training plan field (including 175 national projects), and 152 teachers' scientific research projects with students' participation. There are 36 projects of participating in the development of homemade laboratory equipment, 44 applications for national patents, 18 software copyrights and 36 published papers

Graduates are widely welcomed by the employment companies; the average employment rate is more than $90 \%$ in the past three years. The graduates employed by the domestic top 500 enterprises, governments, institutions and foreign enterprises accounted for about $60 \%$, and the employment rate and employment quality in colleges and universities of Jilin province ranked the top three. The employment companies gave a high evaluation of school's graduates, and they think that the students in our school have the high quality, good basic skills, thinking ability, strong ability to learn, obtain information and use information, certain ability of comprehensive and systematic analysis, and good social adaptation ability.

\section{Conclusion}

By in-depth analysis of higher education teaching reform experience, we put training high quality applied innovative talents as the goal, innovative education as the main line, based on school discipline superiority characteristic and the practice teaching platform construction, improving the practice teaching system and teaching model reform practice as the means to update the education teaching idea, highlight the important role of practice teaching, implement the whole process of education practice, and explore a successful way for local colleges and universities to train applied innovative talents.

\section{References}

Kang, T., Huang, H.-C., \& Peng, Q.-K. (2004). Establishing practical teaching system and improving the level of practice teaching. Journal of Jiangxi Agricultural University (Social Science Edition), 2004(2). http://dx.doi.org/10.3969/j.issn.1671-6523.2004.02.041

Lan, G. (2007). Construction of practical teaching mode of newly-built local undergraduate colleges and universities. Journal of Chinese Higher Education Research, 2007(8). http://dx.doi.org/10.3969/j.issn.1004-3667.2007.08.013

Liao, S.-G. (2005). Innovative practice teaching: the adaptation of personnel training mode in university to the employment market's demand. Journal of Contemporary Education BBS, 2005(1). http://dx.doi.org/10.3969/j.issn.1671-8305.2005.01.030

Liu, S.-Y. (2012). Exploration and thinking over the practice education in colleges and universities. Laboratory Research and Exploration, 2012(6). http://dx.doi.org/10.3969/j.issn.1006-7167.2012.06.028

Mao, M. (2007). The construction of teaching quality engineering guarantee system with special attention to teaching. Journal of Chinese Higher Education Research, 2007(9). http://dx.doi.org/10.3969/j.issn.1004-3667.2007.09.014 
Wu, L.-E. (2004). The construction of practical teaching systems of higher education at the university under the background of popularization. Journal of Higher Education BBS, 2004(6). http://dx.doi.org/10.3969/j.issn.1671-9719.2004.06.029

Xia, J.-G., \& Liu, X.-B. (2007). Applied undergraduate education: Background and essence. Journal of Higher Engineering Education Research, 2007(3). http://dx.doi.org/10.3969/j.issn.1001-4233.2007.03.020

Yang, Z., \& Wei, Y.-M., Jiang, J., \& Yang. P. (2013). Exploration of practical teaching mode of cultivating the ability of application. Journal of Higher Education Research, 2013(1). http://dx.doi.org/10.3969/j.issn.1672-8874.2013.01.005

Zhao, Y. (2003). The construction and implementation of practical teaching system in colleges and universities under the new situation. Journal of Chemical Industry of Higher Education, 2003(4). http://dx.doi.org/10.3969/j.issn.1000-6168.2003.04.037

\section{Copyrights}

Copyright for this article is retained by the author(s), with first publication rights granted to the journal.

This is an open-access article distributed under the terms and conditions of the Creative Commons Attribution license (http://creativecommons.org/licenses/by/3.0/). 